\title{
Big Leagues: Specters of Milton and Republican International Justice between Shakespeare and Marx
}

Surprisingly enough, discussions of Hamlet have recently become deeply intertwined with debates about international law and international justice. A precipitating cause is Jacques Derrida's late work Specters of Marx, in which Shakespeare's Hamlet played a crucial organizing role. Because of Specters of Marx, whose subtitle is The State of the Debt, the Work of Mourning and the New International, Hamlet is now, in Nicholas Royle's words, "an exemplary text for thinking together about the current state of the world." "What has also emerged as scholars have returned to Karl Marx and Shakespeare through Derrida might be called a literary history of the International. But if we define the "literary history of the International" loosely as the nexus of texts, conditions, ideas, and contexts that informed Marx and Friedrich Engels' internationalism, the story now skips easily — too easily_from Shakespeare, to Marx, to Derrida along the path of "hauntology" proposed there by Derrida himself_-Derrida's playful substitute for "ontology," which he proposes in part in order to theorize literary history's claims on the present. ${ }^{2}$

Among the aspects of the literary history of the International that Specters of Marx has made it surprisingly easy to pass over is precisely what Engels first, then Marx, in late 1847 , admonished their international readership not to neglect: "Let us never forget Milton, the first defender of regicide." 3 Ghosts are choosy about whom they visit. From the perspective of Derridean "hauntology," little between Shakespeare and Marx holds much significance except that the Ghost of Shakespeare's Hamlet traversed time to visit Marx. To insist that Milton's republicanism, as seen in Paradise Lost among other places, also belongs alongside Hamlet in a literary history of the International is, however, a key aim of this essay. A critic of republicanism, Derrida himself diffused objections that he wrote from "conservative or reactionary motivations or even [from] moderate right-wing or republican positions"; but that should not obscure nineteenth-century radicals' own interest in republicanism-registered, for example, by the late 1847 call for internationally minded Europeans to honor the regicide Milton, or even the fact that George Julian Harney's newspaper in which The Communist Manifesto first appeared in English, in 1850, was called The Red Republican. ${ }^{4}$

The nineteenth century brought distinctly new forms of international organizing. On the right, the early nineteenth century saw European monarchs' intimately coordinated defense of monarchism following the destabilizing American, French, and (less often mentioned) Haitian revolutions. ${ }^{5}$ On the heels of this "royal international," industrial-age, Manchester School thinkers like Richard Cobden developed a liberal 
internationalism premised on coordinating taxes and tariffs for unimpeded international commerce. Left internationalism, however, was an especially rich and shifting terrain. It included a range of proletarian, republican, and "Yankee" internationalisms, including among others the "Chartist internationalism" of the Fraternal Democrats, the Democratic Friends of All Nations, the League of the Just, the People's International League, and ultimately the Communist League and the International Working Men's Association (the last subsequently known as the First International). ${ }^{6}$

As we will see, nineteenth-century radical internationalism relied heavily on texts and figures from prior eras. In fact, Milton's republicanism was a key element that radicals including Marx and Engels used to forge the international solidarity necessary for the construction of what, throughout this essay, I will call the "big leagues" of the nineteenth century, by which I mean the ambitious radical international associations and organizations created amid the social and political conflagrations of the nineteenth century. Across a range of overlapping radical contexts, union, cooperation, association, and collaboration became prominent themes. Their importance found loudest expression when division felt most real. In his Republican Catechism, one of the founders of the People's International League, W. J. Linton, offered a succinctly teleological distillation of the republican emphasis on leagues and associations. As he put it, "The sum of our Republican Faith is this: the perfectibility of Humanity through organization."7 Railing, as a republican, against the "monarchic governments" standing in the way of a "Holy Alliance of the Peoples," Giuseppe Mazzini likewise announced in 1849 that "the lessons of the past can be summed up in a single word: union." " And of course Marx and Engels, developing an "everexpanding union of the workers" implored, "WORKING MEN OF ALL COUNTRIES, UNITE." It is in this context that there remains a puzzle in Derrida's choice to install a tragedy about "something ... rotten in the state of Denmark" at the center of a "New International" while excluding something like Paradise Lost, in which "nations [are] yet unborn." ${ }^{10}$ Historians of nineteenth-century reading have shown that Shakespeare and Milton were both central to the mid-nineteenth-century radical canon. ${ }^{11}$ Paradise Lost itself could offer compelling visions of global union. Is Derrida's, then, a retreat from the republican "specter of Milton"? ${ }^{12}$ Difficult to say, of course. But it is instructive to consider differences between the Shakespearean legacy that Derrida prizes and the republican international legacy that in recent accounts has seemingly fallen from view. Since Specters of Marx exhibits strong interest in theology, the most salient issue is not Milton's Christian theodicy-Paradise Lost's famous project of justifying the ways of God to man. Rather, it is the republican dimension of Milton's thought that crystallizes Derrida's aversion in Specters of Marx to precisely those largescale, international political organizations to whose formation and continuity Milton's legacy was put in the nineteenth century and against which Derrida offers his "New International" as a putative remedy—Derrida's aversion, in other words, to "big leagues."

Even though the selective literary historiography of the International in Derrida's Specters of Marx separated the republicanism of Milton's Paradise Lost from Shakespeare's Hamlet, it is not the purpose of this essay to install Paradise Lost where Hamlet once, albeit briefly, reigned. Rather, challenging certain biases against other types of 
big leagues, the argument here is that Paradise Lost belongs to the literary history of the International in a way not distinct from Hamlet but in fascinating and heretofore too-little noticed league with it. In the usual view, Paradise Lost does not ally with Shakespeare's play in any significant way-Harold Bloom, for instance, writes of Milton's “agon” with Shakespeare's Hamlet in Paradise Lost_but I read Paradise Lost as an example of an early, important engagement, both with Hamlet and the conceptions of international order dramatized therein. ${ }^{13}$ To borrow a line from Hamlet that Marx made famous, Shakespeare himself may have been Milton's "old mole."

What follows comes in four parts. Beginning with Derrida, the first part explores the vision of the New International that Derrida constructs through his engagements with Shakespeare and Marx. The second part looks briefly to Marx and Engels' midnineteenth-century context to emphasize the role of Miltonic republicanism in the making of the nineteenth-century's big leagues. While most scholarship separates Marx's and Derrida's engagements with early modern writers from accounts of those writers' more immediate receptions, the third part entails a reading of Paradise Lost that measures the poem's distinctly republican internationalism against the deconstructionist internationalism Derrida uses Hamlet to advance. By studying Milton's republican internationalism against the backdrop of Marx and Derrida, this section challenges certain divisions of labor between literary theory and literary history. The key figure in this discussion is Milton's Satan, who, I argue, undergoes a transformation in the poem from a Hamlet-like avenger into a Claudius-like usurper and thus offers an important lens on Milton's larger republican internationalist project, which involved severing the purported conceptual ties between violent justice against tyrants and the Satanic. Building on the first three parts, the fourth part asks, finally, what might adding Paradise Lost to the literary history of the "old International" bring to the "New International"? The aims of the essay are ultimately two: first, to involve Milton in a fuller reception history of Hamlet that can better account for the play's fusion, as in Marx and Derrida, with theories and articulations of international justice; and second, to insist that Milton's republican poem, pace Derrida, must belong to any literary history of the International between Shakespeare and Marx.

\section{Shakespeare and the New International}

Before moving on, a few words about Shakespeare's role in accounts of the International in Derrida and Marx: Marx's love for Shakespeare and his materialist critiques of what he occasionally saw as the phantasmagorical ideals associated with bourgeois international law are both becoming better known, and recent scholars have amplified the more latent aspects of the latter. ${ }^{14}$ For Marx, international law, in particular the ideology of natural rights, served ruling-class interests by hardening global inequities within supposedly equalizing legal forms. Meanwhile, Derrida's call for an unceasing deconstructionist critique of international law in the "spirit" of Marx has itself been widely embraced in critical legal studies. Remarkably, figures from Hamlet are central to both visions. Although Marx and Derrida differ significantly, each emphasizes the gap between international "law" and international "justice" by invoking Shakespearean figures of traversal. In Marx, the "old mole" to which Old Hamlet is compared in Hamlet emblematizes international justice emerging into the corporeal, 
material world: international justice becoming material through revolution. Derrida, on the other hand, emphasizes that the Ghost in Shakespeare never rematerializes into corporeal form. According to Specters of Marx, international justice and international law are irremediably alienated from one another, and it was Marx's mistake to lodge hope in the incorporation - the making manifest - of international justice.

Although present in images and echoes, Hamlet had gone unnamed in the Communist Manifesto. Presumably, this was partly because Marx and Engels understood themselves as heirs of processes whereby "intellectual creations of individual nations become common property," and "a world literature" had been forged out of "national one-sidedness and narrow mindedness." 15 Shakespeare's portrait adorned the walls of the branch of the international association that sponsored the Communist Manifesto, the League of the Just, and his language and images seeped into the Communist Manifesto itself like so much common property of an international political movement. ${ }^{16}$ "Few texts," says Derrida, "have shed so much light on law, international law, and nationalism" as Marx and Engels' Communist Manifesto, a point to which the treatment of Shakespeare there by two Germans in exile subtly testifies. ${ }^{17}$ On the other hand, Derrida's choice of Hamlet as a key vehicle for such thinking about international law and nationalism has helped ensure Hamlet a belated place in the extraordinary nineteenth-century project that, in Derrida's view, "was essentially distinguished from other labor movements by its international character" and that, in "present[ing] itself as geo-political . . . inaugurat[ed] the space that is now ours." 18 In Richard Wilson's reading, Derrida is like Hamlet's "night-watchmen on the ramparts of a tired 'Old Europe,'” who in welcoming Shakespeare and his ghost becomes the exemplary practitioner of a new politics of European hospitality. ${ }^{19}$ Although some commentators on Specters of Marx have preferred to highlight Derrida's treatments of messianism, time, and the other, it may be that one of the book's most underappreciated achievements is that Derrida has made Hamlet a cornerstone of the literary history of the International. ${ }^{20}$ If many of Derrida's contemporaries can be accused of precipitating a "shortage of long-term thinking," Derrida successfully resists what Jo Guldi and David Armitage call the "spectre ... haunting our time: the spectre of the short term." 21

Despite such real merits, the Derridean method of "hauntology" has also, paradoxically, effaced the literary history of the International between Shakespeare and Marx. There is more to be said than that Marx loved Shakespeare. Not only do precursors such as the Fraternal Democrats, the Democratic Friends of All Nations, the League of the Just, the People's International League, and so on go unmentioned in Derrida's work, so does Marx's vast interest in world literature, which S. S. Prawer thoroughly catalogued in $1976 .{ }^{22}$ Among an extensive field of possibilities, Derrida singles out Hamlet in order to critique political actions founded on ambiguously unauthorized accounts of international justice. Derrida's attraction to the Ghost stems precisely from the ambiguity or "undecidability" of Hamlet's justice. Coleridge had long before observed how "in other writers we find the particular opinions of the individual; in Massinger it is rank republicanism ... but Shakespeare never promulgates any party tenets." ${ }^{23}$ It may be that Hamlet has justly punished tyranny, but Derrida understands 
well that the tragic end of the drama can also confirm Claudius's antirepublican argument that "divinity doth hedge a king." 24

Why Derrida preferred Shakespeare over Milton will become even clearer with reference to Derrida's conception of the New International and its studied departure from republicanism in theory and practice. The "New International" of his subtitle, Derrida says, is one of "a profound transformation, projected over a long term, of international law, of its concepts, and its field of intervention." 25 Marx haunts Derrida's project like the Ghost of Hamlet because Derrida's vision is at once distinctly post-Marxian and also offered, Derrida says, under the inescapable Marxist "spirit" of justice that demands a deconstructionist critique of international law.

Derrida's New International conjures the Marx who was a thinker of global economics and critic of international law, but it also tries to exorcise the Marx associated with positive "ontological content" and "worldwide forms of social organization." ${ }^{6}$ Using Hamlet's "time out of joint" as an epigraph, Derrida finds in Shakespeare inspiration for a quasi-anarchist project that replaces the positive coordination and solidarity of institutions, such as an international workers movement or the even the UN, with a "counter-conjuration" of negative critique. Aijaaz Ahmad calls it an "anti-politics"; Terry Eagleton lambasts it as "Marxism without Marxism."27 In a long but significant passage, Derrida describes his New International as an

... almost secret link, as it was around 1848 . . It is an untimely link, without status, without title, and without name, barely public even if it is not clandestine, without contract, "out of joint," without coordination, without party, without country, without national community (International before, across, and beyond any national determination), without co-citizenship, without common belonging to a class. The name of new International is given here to what calls to the friendship of an alliance without institution among those who . . . continue to be inspired by at least one of the spirits of Marx or of Marxism. . . . in order to ally themselves ... even if this alliance ... takes the form of ... a counter-conjuration, in the (theoretical and practical) critique of the state of international law, the concepts of State and nation ... in order to renew this critique, and especially to radicalize it. ${ }^{28}$

Derrida's "New International" is above all a deconstructionist aporia. His "alliance without institution" is a negative community, one in a way historically prior to the big leagues and institutions of neoliberal international law but that also arises in opposition to them. Significantly, Derrida's New International has less interest in radicalizing international institutions than in radicalizing the critique of them. Milton's Satan might have praised Derrida's paradoxical account for "build[ing] / . . ruin." 29 Derrida resists the mediating and de-democratizing power of big leagues, parties, and international labor unions and finds power enough in the "almost secret link" of critique.

In this project of developing a New International so nebulous that Ahmad suggests it resembles a small Masonic order, Shakespeare's Hamlet plays multiple roles. ${ }^{30}$ Derrida's description of his New International itself derives directly from Shakespeare's language. Central is the scene in Hamlet I.5, quoted by Derrida at the outset, 
in which Hamlet, Horatio, and Marcellus swear never to speak of the ghost nor to disclose the reasons for Hamlet's "antic disposition." ${ }^{11}$ The attractions of the scene lie in its characteristics of smallness and secrecy, as seen in the pressure Derrida puts on the word "conjurer," in French a "conspiracy" or "co-swearing." Derrida incorporates Shakespeare's language into his own as Derrida's "secret” echoes Hamlet's “you'll be secret?"; "friendship" resembles Hamlet's repeatedly invoked "good friends"; and "without common belonging to a class" suggests Hamlet's alliance of "friends, scholars, and soldiers." 32

Derrida implicitly casts himself as Hamlet's title character-a privileged inheritor called by Marxism from beyond its grave to critique international law. But much as Hamlet's position remains fraught, Derrida's identification with Hamlet also registers Derrida's ambivalence about the Marxist inheritance. Hamlet's dithering and Derrida's deconstruction emerge as the kindred, almost symptomatic, projects of princes uncomfortably bound to uninvited specters. In Derrida's reading, Hamlet "curses [his] destiny . . . to do justice, to put things back in order, to put history, the world, the age, the time upright." 33 Derrida indicates that he feels similarly. In part, "deconstruction is justice" precisely because international law is unjust, "out of joint." ${ }^{34}$

Derrida's polyvalent Ghost or specter sometimes stands for Marx, sometimes for history's varied Marxist projects and big leagues, and sometimes for Marxist ontology, thus offering Derrida multiple ways to theorize the past's claims on the present, including the valuable sense that "the living present is scarcely as self-sufficient as it claims to be." 35 But among the Ghost's many significations in Specters of Marx, perhaps the most important are the two main ways in which the Ghost of Hamlet figures Derrida's New International: first, as immaterial and second, as a return.

Derrida first implies an analogy in which Derrida's New International is to leagues and institutions such as Marx's International Workingmen's Association as Old Hamlet's Ghost is to Old Hamlet. Against the corporeal Old Hamlet of Marx's First International, Derrida provides in the Ghost an evocative if ambivalent figure for an immaterial New International somehow both present and devoid of ontological content. The terms "concrete" and "real" admittedly create the characteristic deconstructionist aporia, but the fundamental move in the text is nevertheless one of "disincarnation." 36

Seen as a return, Derrida's New International is also, however, a quasi-messianic second coming of an even older International, one that in this context is seen to predate the hierarchical party apparatuses and formalized labor unions that would emerge through the increasingly politicized workers movement of the late nineteenth century. Since 1848, in Derrida's account, was the year that the Communist Manifesto summoned the "real presence of the specter" in the form of an institutionalized Communist International League, Derrida's call for a "New International” invites a return to that older, "secret," spectral International that predated bureaucracy, statism, Stalin, and Mao. ${ }^{37}$ It was Marx's misstep, in Derrida's estimation, to believe that "the dividing line between the ghost and the actuality ought to be crossed." ${ }^{38}$ Derrida's wish to return to a world "as it was around 1848 " calls to mind a prelapsarian state of original purity characterized by a more spontaneous, uninhibited internationalism, one ultimately sullied by rigid institutions and inflexible ontologies—sullied by the 
commitment, in other words, to the revolutionary thought that the dividing line between international justice and international law ought to be crossed. But ordinary chronology too collapses under the weight of Derrida's deconstruction. Whether or not Ahmad is right that the "anti-politics [Derrida] advocates might well bring us not a 'new International' but a mere Fortinbras . . . , a systemic restoration that comes about through a process that neither his ghost nor Hamlet could anticipate or survive," Ahmad captures Derrida's temporal indecision. ${ }^{39}$ The "New International" returns to a prelapsarian International, but that International, the alliance without institution, is itself counterpoised against an archaic, "very old order" emblematized by the name of Fortinbras or even Shakespeare. Put slightly differently, the secret conspiracy emerges only after "time is out of joint."

\section{Karl Marx, Republicanism, and "the Hallowed Shrine of Milton"}

Marx, the Shakespeare lover, used Hamlet differently. The Communist Manifesto began in Shakespearean tones with the "specter . . haunting Europe." 40 This specter, the international working-class revolution, is precisely the one that Marx aimed to materialize. More elaborately, in The Eighteenth Brumaire (1852), the Ghost of Hamlet's father figured the international working-class revolution postponed but not defeated by Louis Bonaparte's temporary victory over red republicanism. ${ }^{41}$ Like an Industrial Age Claudius interfering with the rightful inheritance of the working classes, it was Louis Bonaparte, Marx suggested, who had now put "time out of joint." In figuring the international working-class revolution as Hamlet's Ghost, however, Marx stresses a far more material Hamlet than would Derrida at the end of the Cold War, or Hegel before him. Marx chooses for direct allusion Hamlet's address to his father's ghost in I.5 in which Hamlet calls his father an "old mole," a miner, and "a pioneer," and Marx even misquotes Hamlet's "Well said old Mole" as "Well-grubbed," giving the allusion an even more evocative association with materiality and proletarian physical labor. ${ }^{42}$ A perspicacious reader, Marx had picked up on Shakespeare's emphases on land and mining, operative not only in Hamlet's address to his father's ghost but also in the graveyard scene in which the gravedigger responds to Hamlet's question of whose grave it is with the resonant answer, "Mine, sir." 43 Marx and Engels' comment in The Communist Manifesto_- "What the bourgeoisie ... produces, above all, is its own grave-diggers"-is equally dialectical and Shakespearean. ${ }^{44}$

Although it is less of a critical commonplace, Marx and Engels' writing was also strongly Miltonic. As Paris correspondent for the Chartist publication The Northern Star, Engels had attended a covert banquet of French and Swiss radicals at which one speaker distinguished the cosmopolitan aims of French republicans from England's putative commitment to "egotism against fraternity." ${ }^{45}$ It was in his report about the speech that Engels, himself raised among strongly Pietist stock, admonished readers to "never forget Milton, the first defender of regicide": Milton's international republicanism put the lie to the canard about England's "egotism." 46 Marx reprinted Engels' criticism, including the Milton invocation, with a sharp headnote advocating, in terms recalling Milton's Areopagitica, self-criticism among European democratic republicans. The article's main purpose, however, was to confirm Marx's publication's likeminded wish to "protest against . . . illusions which are in direct and hostile opposition to the 
trends of modern democracy and which should be abandoned if the union of democrats of different nations is to remain more than an empty phrase." ${ }^{47}$ Although Milton did "stand [ . . ] a the beginning of the bourgeois hegemony over which Marx casts his retrospective glance," there was an international dimension to Milton's bourgeois republicanism that has subsequently tended to go underemphasized in literary history that Marx, Engels, and other nineteenth-century radicals wanted to promote. ${ }^{48}$

A "radical rereading of Milton" that occurred in Britain blossomed internationally as well, fueled by French and German editions of Milton's Defense and the "radical classic" Areopagitica. ${ }^{49}$ Helen Maria Williams reported in her Letters Written from France that Milton had become "one of an international group of eight 'friends of liberty' whose busts were commissioned to adorn the interior of the Jacobin Club in Paris" as early as 1792, and Milton's legacy influenced radical Francophone, Anglophone, and even Grecophone communities internationally through the labors of figures like Thomas Hollis and Gabriel Riqueti, comte de Mirabeau, both of whom sprinkled editions and translations of Milton's works "like rain on thirsty intellectual and political soil abroad." 50 Early in his career, when Marx's "open republicanism was the result of a complex process of radicalization in which [his] involvements in philosophical, political, and theological debate [was] inextricable from [his] reactions to actual politics," Marx traversed a path blazed almost exactly two hundred years earlier by Milton's Areopagitica (I644) in defending the freedom of the press. ${ }^{51}$ Recalling that "English history... . has sufficiently well demonstrated how the assertion of divine inspiration from above gives rise to the counter-assertion of divine inspiration from below," Marx observed that "Charles I went to the scaffold as the result of divine inspiration from below." ${ }^{2}$ Whether Marx had Milton specifically in mind is unknown, but Milton's words had recently been circulating vigorously within "the fluidity of associational life." 53 The preceding decades had seen booming international interest in Milton's prose-partly as a result of the discovery of Milton's theological commonplace book De Doctrina Christiana, first published in 1825 - but also in more explicitly politicized international contexts that included the republican movements in France and Germany, the Chartist movement in England, and the growing antislavery campaign in America, all culminating in the I840s with the bicentenary of the English Revolution. ${ }^{54}$

Looking back on Milton's era, Marx saw a historical dialectic founded on inspiration in which freedom of the press, republicanism, and revolution were closely joined. Milton in The Tenure of Kings and Magistrates and other pamphlets had stridently insisted that "kings, if they offend, have no privilege to be exempted from the punishments of Law more than any other subjects." ${ }_{55}$ In strategic political terms, such republicanism was valuable to Marx and Engels in the I840s as they forged international coalitions capable of withstanding disorienting waves from theory and practice. In a political context whose globe-spanning though difficult-to-align groups included anti-imperialists, democratic republicans, democratic socialists, Christian socialists, Chartists, abolitionists, fraternal democrats, Young Europeans, utopians, pantheists, perfectionists, and communist workers' parties, Milton's republicanism served as a useful, if unlikely, bridge.

If eighteenth-century aristocratic Whigs who revered Milton typically downplayed 
Milton's international significance, instead propagating a tidy narrative of English or British liberty, nineteenth-century radical internationalists were not so constrained. ${ }^{56}$ Radicals concerned primarily with international justice put Milton at the head of an antityrannical republicanism belonging to the world at large. Having already been wielded successfully in the Romantic campaign against slavery in Britain, Milton continued to offer powerful proof texts for North American abolitionists and their allies abroad. ${ }^{57}$ That same republican critique of slavery was so amenable to the socialists' and communists' critique of "wage slavery" that "socialism was nurtured on an attachment to [the] republican ideal, applying it to more or less revolutionary effect in criticism of emerging employment relationships." 58 At the same time, Milton's Christian republicanism, when not pragmatically stripped of its theological commitments, kept the political tent open to those arguing radical political positions on Christian grounds such as the "leading figure of the London branch of the League of the Just," Karl Schapper, who called Christ "our first republican." 59 Many midnineteenth-century radicals exhibited considerable "tolerance for ideological opacity which allowed them to mingle bourgeois liberal and Marxist doctrines with little sense of their fundamental incompatibility." ${ }^{60}$ Milton, therefore, became a figure whose republicanism and Christianity facilitated exchange within what Timothy MesserKruse calls "the Yankee International," the tenuous alliance of Continental and North American reformers that combined practical Christianity, republicanism, socialism, and communism in agitating for justice for slaves, laborers, and women alike. ${ }^{61}$ The radical London bricklayer, journalist, and First International committeeman George Howell, a strong sympathizer with Abraham Lincoln and the Union, began his career by borrowing Paradise Lost from a Wesleyan mentor, then establishing a coffeehouse "Milton Club" dedicated to Milton's republican prose. ${ }^{62}$ In an era dedicated, in Giuseppe Mazzini's words, to "lay[ing] the foundations for future international friendship based on mutual esteem," Miltonic republicanism meant potent new forms of horizontal international alliance and allegiance. 63 "When universal Democracy shall dawn upon the world," the Chartist Circular had crowed in I84I, "mankind will light the torch of liberty and equality, at the hallowed shrine of Milton." ${ }^{64}$ Milton, after all, had penned the "unanswerable argument against the divine right of kings." 65

\section{Satan's Mousetrap: From Hamlet to Paradise Lost}

Even as Milton's prose veered in and out of fashion, Paradise Lost had become "world literature," and the epic itself offered instruction in how to hold fast in international union. Fredric Jameson may fault Milton's poem for its "elision of collective praxis and action," but this criticism has difficulty withstanding scrutiny. Milton, known in the radical press as the "poet of paradise," at one point inscribes collective action as the very telos of the natural order, calling attention to the "Pattern of just equality" to be found in ants who "joined in . . popular tribes / Of commonalty." ${ }_{66}$ Adam and Eve are themselves corporate bodies who contain within themselves the collectivized whole of humanity. ${ }^{67}$ Marriage too for Milton is understood as a "nuptial league." 68 Milton's Satan further shows where the Jamesonian criticism falls flat. ${ }^{69}$ With excellent reason, Satan has appealed to various internationalist thinkers up to and including the pan-Africanist Malcolm X and the humanist internationalist Phillip Pullman, and it 
is clear that no account of the literary history of the International should ignore him. ${ }^{70}$ Against a God he sees as a kind of Claudius, Milton's Satan develops a union solemnized, in Satan's words, in "firm faith, and firm accord." 71 His very first speech in the poem recalls how Beelzebub and the other devils "Joined with me once" in "mutual league, / United." 72 At first not altogether different from Hamlet's or Derrida's "counter-conjuration," Satan's International similarly joins scholars and soldiers by uniting devils like the scholarly Belial—he of "words clothed in reason's garb" —and the martial Moloch, "the fiercest spirit / That fought in heaven." ${ }^{33}$ Formed, as Adam says to Eve, with "nations yet unborn," Satan's union can indeed be seen as a kind of "International before, across, and beyond any national determination," and the criticism leveled by Jameson would, at the very least, seem to be misplaced. ${ }^{74}$

While such unions were indeed attractive to Romanticism's many "Satanic" revolutionaries, the poem in the end offers an even more potent version of international union. As the epic begins, Satan's International has already devolved into "misery . . . joined / In equal ruin," its supposed "glorious enterprise" already a distant memory. ${ }^{75}$ Alluding to the Iliad's catalogue of ships, Milton's catalogue of devils in book I invokes a certain kind of epic internationalism — the coming together of the Achaeans for the Trojan War-but that catalogue, as readers know, inaugurates not a New International but instead the national epic of Greece. ${ }^{76}$ Milton's own catalogue of devils pointedly emphasizes the distinctive national instantiations of idolatry. "Explicitly, self-consciously . . . a battle for the hearts and minds of humanity," Milton's poem aspires to international scale without reducing individual humans to mere numbers. ${ }^{77}$

Milton's allusions to the Iliad lay bare the egotism at the heart of Satan's International. Engels had responded to Dijon's self-regarding French chauvinism by saying:

Democrats of other nations ... [are] Quite ready to give up the harshness of their own nationality, [but] they expect the same from the French. They will not be satisfied in the assertion, on the part of the French, that they are cosmopolites; assertion which amounts to the demand urged upon all others to become Frenchmen. ${ }^{78}$

Against Satan's self-regarding — and therefore tenuous - union, their counterparts in Milton's unfallen angels remain "Indissoluably firm," having "stood for Heaven, in mighty quadrate joined / Of union irresistible."79 Such moments illustrate how Milton's poetry could work in league with his prose for the construction of a republican international.

They also suggest Milton's engagement with Hamlet. In turning to universal history and the story of those he called "our general ancestor[s]," Adam and Eve, Milton invoked an order prior to the nation, both historically and morally. ${ }^{80}$ That Milton draws from Shakespearean revenge tragedy in doing so is, in a sense, well known. John Kerrigan observes that “if Milton's early plans to write Paradise Lost as a tragedy had been realized, Satan would have resembled the angry and tormented villain-revengers of Jacobethan drama, punishing but also being punished by what he does to Adam and Eve." ${ }^{11}$ And Helen Gardner finds that "Satan is an egoist and Satan is a comic character in exactly the same way as Hamlet" before wondering why Milton 
"turned away from tragedy." ${ }^{2}$ But could Milton's engagement with Shakespeare's great tragedy have been more than a path not taken?

Recent scholarship has illustrated that questions of international justice were already at the heart of Hamlet. While Margreta de Grazia has pierced the Romantics' influential obsession with Hamlet's supposedly remarkable interiority, Carolyn Sale has shown the significance of Tudor-Stuart debates over whether a monarch could lawfully alienate natural resources in the earth by granting mining monopolies to foreign corporations. ${ }^{83}$ Drawing our attention to the German mining firm to whom Queen Elizabeth had granted a monopoly to extract "English" treasure, Sale unfolds a picture of Shakespeare who can be seen, without too much historical foreshortening, as a Marxist critic of international law avant la lettre. The play alludes to the so-called Case of Mines in which Elizabeth defended the royal right to alienate common English inheritance, the mineral treasure of the realm. ${ }^{84}$ In its original context, Sale suggests, Shakespeare's play criticized Elizabeth's brazen willingness to "convert [ . . ] common holdings into the private holdings of the [crown]" and thereby to enrich foreign investors at the cost of England and its local villages, or "hamlets." ${ }^{85}$ Sale implies that Shakespeare's play critiques a ruling-class internationalism in which European elites are all too comfortable collaborating in an international project of seizure and despoliation. Internationalism in such a picture is what Tom Nairn, invoking Hamlet in his own neo-Marxist critique of internationalism, calls a "well-born ghost"- to be exorcised by an early version, as it were, of painting nationalism red. ${ }^{86}$ When Shakespeare's Claudius dispatches Hamlet to England for execution, the international has become a space of unspoken leagues between great sovereigns and their occasional aristocratic allies who conspire to uphold one another in safety and wealth against dispossessed citizens like Shakespeare's gravediggers and the popular followers of Laertes. ${ }^{87}$ Even so, as Christopher Hill reminds us, the truth about the "royal international" could occasionally slip: "There is an implicit tie amongst kings," James I/VI confided to one courtier, "which obligeth them, though there be no other interest or particular engagement, to stick unto, and right one another upon insurrection of subjects." 88

The concerns I have been sketching illustrate why European movements against monarchism and against unjust property relations were interrelated and continually fed one another from the early modern period onward. Among Milton's seventeenthcentury contemporaries was the True Leveler or Digger Gerrard Winstanely, whose assessment that "law is but the strength, life, and marrow of the kingly power, hedging some into the earth, hedging out others; giving the earth to some, and denying the earth to others," was but one dimension of a mid-seventeenth-century radical movement as capable of critiquing royalist legal injustices such as the Case of Mines as of inspiring modern radicalisms: one scholar queries, "Was Marx a NineteenthCentury Winstanleyan?" 89 Winstanley certainly thought, to quote one of Derrida's critiques of Marx, that "the dividing line between the ghost and the actuality ought to be crossed." "That Scripture which says 'the poor shall inherit the earth' is really and materially to be fulfilled," he wrote. ${ }^{90}$ Milton was no True Leveler, but Sale's work on the Case of Mines hints at the possible kinship with Shakespeare and Winstanley in the special vehemence Milton levies on the devils in Paradise Lost who first "Ransacked the centre, and with impious hands / Rifled the bowels of their mother 
earth / For treasures better hid." 11 "The earth itself hath too long groaned under the burden of [kings'] injustice, disorder, and irreligion," Milton complained in I65I. ${ }^{92}$ In Paradise Lost, "earth felt the wound" upon Eve's transgression, and "nature gave a second groan" at Adam's. ${ }^{93}$ As Milton links the Fall with kingship and sheds the imaginative constraints of the nation, Milton offers a distinctly republican vision of international justice.

Milton, as commonwealth polemicist and advocate for regicide, had drawn on plays such as Shakespeare's Macbeth, Richard II, and The Tempest, where he found, in Nicholas McDowell's words, "useful fictive analogues and vivid poetic language" to "engage[] with issues of tyranny, regicide, popular allegiance, and national identity." 94 Describing tyranny's crimes against humanity so powerfully in these tracts that his hand has been seen in shaping "the earliest precedent for trials of modern heads of state," Milton worked tirelessly on behalf of an international climate friendlier toward republican political form. ${ }^{95}$ Whereas kings were seen by many as above international law or at least distinctively protected by it-Milton's French adversary Salmasius, for example, claimed that the "right of kings is based on the law of nations [jure gentium]"-Milton would grant tyrants no more legal status than pirates. ${ }^{96}$ Tyrants like Charles I could be punished because they were "the public enemy of virtually the entire human race," generis humani . . hostis. ${ }^{97}$ This was the Milton unwilling to surrender judgments about international justice to monarchs whom Marx and Engels implored their readers to remember, and this was also a Milton who was indisputably steeped in his Shakespeare.

Milton's first published poem was one he wrote for Shakespeare's second folio in 1632, and Milton first imagined Paradise Lost as a tragedy. In his Elegia prima, written from London in 1626 for his friend Charles Diodati, Milton extols the sad pleasures of London tragedy while explicitly affirming his own visits to the theater. ${ }^{98}$ Milton's father had been a trustee in London's Blackfriar's playhouse and may have written the poem in Shakespeare's first folio ascribed to "JM." 99 Literary critics typically partition Shakespeare and Milton into separate worlds, but from Milton's A Mask, which drew from The Tempest and King Lear, to Samson Agonistes, where Samson's tragic marriage to Dalila reworks Othello's constitutive exogamy, Milton's poetic career, in Ann Baynes Coiro's words, was "a series of resistances to the alienation of drama from serious inquiry." ${ }^{100}$ There may also be echoes or even larger debts to Hamlet in the prose. Repeatedly taking up the question of the "thingness" of kingship in The Tenure of Kings and Magistrates, Eikonoklastes, and his two Defenses of the English People, Milton not only showed strikingly pragmatic flexibility, as Joad Raymond shows, but he also may have been provoked by Shakespeare's regicidal Hamlet, who had similarly affirmed to Rosencrantz and Guildenstern that "the King is a thing." ${ }^{101}$ Raymond rightly cautions that "it is hard to assess the extent to which republican apologists selfconsciously echoed the word games of Hamlet," but the likelihood is increased given antiroyal sentiments in Shakespeare's Case of Mines allusions and if we combine such a possibility with the echoes of Hamlet in Paradise Lost. ${ }^{102}$

Crucially, Milton places the international order under the governance of all the children of Adam and Even and not just kings and aristocrats. This required dissociating two concepts heretofore closely linked, violence against kings, on the one hand, 
and the Satanic, on the other. The character of Hamlet was both help and hindrance in this task of decoupling violence against kings and evil. Like Derrida, Milton too understood how equivocal Hamlet could be made to seem. For royalist readers, Hamlet could be an object lesson in the tragic effects of a mad subject taking justice into his own hands, his dubious inspiration and envious violence allied, naturally, with the Satanic.

But, as Raymond Williams once observed, Milton was a writer "who totally committed himself to a particular side and cause, who temporarily suspended what you call literature, but not in fact writing, in [the English Revolution]." ${ }^{103}$ Williams continued:

These are two possibilities for any highly conscious person in a period of crisis-a kind of commitment which involves certain difficulties, certain naivetes, certain styles; and another kind of consciousness, whose complexities are a way of living with the crisis without being openly part of it. ${ }^{104}$

Milton, we might say, was a writer of the first stripe working in the shadow of the second. The result is a poem with dueling allusive structures. Satan sometimes seems like a dispossessed Hamlet, plotting just revenge on a God cast as Claudius. Satan's God is an ur-Claudius who has unbalanced the political order of heaven by illicitly installing a new successor, the Son. Like Hamlet, Lucifer the brightest of the angels was heir apparent; and Heaven, in Satan's eyes, was his "just inheritance."105 Like Claudius, God too has maintained enough legitimacy to be able to wield the powerful organs of statecraft against the dispossessed. If Shakespeare's Claudius remains buttressed by a network of counselors, watchmen, warriors, spies, and diplomats, likewise does Milton's God. God's "watchful Cherubim . . . . . . / Spangled with eyes more numerous than those / Of Argus" guard Paradise like a biblical Elsinore while his ambassadors to Paradise, Raphael and Michael, whom God "sends upon his high behests / For state," recall Claudius's Voltemand and Cornelius, whose "dilated articles" represent their own sovereign in affairs with an unruly client state (Norway and Paradise, respectively). ${ }^{106}$ It matters that Heaven operates very much like an elective monarchy. ${ }^{107}$ Although Milton risks heresy to write it, God "appoint[s]" his Son because of merit rather than hereditary right, and it is precisely God's claim in a putatively meritocratic Heaven that his Son is "worthiest to be heir" that gives rise in the first instance to Satan's sense of “injured merit" and, in the second, to Satan's conspiratorial feigning. ${ }^{108}$ Satan is like Hamlet not least because Heaven appears to him like Claudius's Denmark.

But Satan's real motive is arrogation of power. He is the poem's true Claudiusfigure, justly punished by the poem's ultimate hero, the Son. Milton did not miss how much the "orchard" where Shakespeare's "serpent" Claudius had killed Old Hamlet resembled the Fall in Eden. ${ }^{109}$ Recalling Claudius perched with poison at the "porches of [Old Hamlet's] ears," Milton puts his Satan "close at the ear of Eve / Assaying . . . to reach / The organs of her fancy." 110 When confronted by Gabriel for the transgression of escaping from hell, Milton's Satan very nearly quotes the words that Shakespeare gives to Claudius at Claudius's most deceptive. In the council scene of Hamlet I.2, Claudius speaks disingenuously of "weighing delight and dole" when 
he justifies his marriage to Gertrude so soon after his brother's death. ${ }^{11}$ Milton's Satan nears this same phrase of "delight and dole" with an address that, while meant to be self-exculpating, in fact becomes unintentionally self-condemning through the echo of Claudius. Both are caught "pretending . . . / Wise to fly pain." ${ }^{112}$ Satan pleads:

Who would not, finding way, break loose from hell,

Though thither doomed? ...

And boldly venture to whatever place

Farthest from pain, where thou mightst hope to change

Torment with ease, and soonest recompense

Dole with delight. . . . ${ }^{113}$

The allusion to Claudius pierces Satan's self-aggrandizing revenge plot. For Satan, to be the Prince of Darkness is to imitate the Prince of Denmark. For Milton's godly republican readers, however, Satan is far from the tyrant slayer he thinks he is.

Satan's revenge plot works through Hamlet-like misdirection. In Satan's plot against a God seen as Claudius, Adam and Eve become a dumb show performed on a garden stage. His approach to Adam and Eve reflects a cunning instrumentality, one source for which can be identified in Hamlet's manipulation of the Mouse-trap players. To be an actor in Satan's sense is not to have the agency supplied by free will; rather, it is to perform, quasi-mechanistically, the work of an external author. For Satan, then, the Fall is "the thing / to catch the conscience of the king." ${ }^{114}$ And yet Milton suggests that "our general ancestors" are actors in a far different sense than Satan would have them be. In Areopagitica, Milton emphasized Adam's free choice to fall, otherwise "he had bin else a meer artificiall Adam, such an Adam as he is in the motions." 115 Although Satan is content with a radical instrumentality that mirrors Hamlet's manipulation of less powerful playthings, Milton's account of human agency repudiates that theatricalized vision. Of course, the fact that Adam and Eve are more than dumb actors ("merely artificial") is one of the preconditions for the Fall, but Hamlet as a context indicates that will-including collective political will-is not merely Satanic.

Indeed, there is an easily lost bathos to Satan's self-aggrandizing heroism. Satan's revenge plot, unlike Hamlet's, is effectively self-authorized. In Hamlet, a play that foregrounds letters, many of the plots and subplots turn on distinctions of sender and sent, and Shakespeare asks his audiences to evaluate the Ghost of Hamlet as a kind of authorizing sender and the avenging Hamlet as the authorized sent. By contrast, Milton's Satan is his own authorizing Spirit. Speaking with the angel Zephon, Satan dismisses the lowly angel by saying that he (Satan) will only "contend, . . . / Best with the best, the sender not the sent." 116 While the gap that Satan highlights between "sender" and "sent," God and angel, is a version of the authorizing relation between Hamlet's Ghost and Hamlet, Milton's Satan conspicuously muddies the distinction. ${ }^{117}$

Nowhere do sender and sent, authority and authorized, merge more clearly than in book 4 of Paradise Lost, where Satan resembles both Hamlet and Old Hamlet's Ghost. Uriel tells Gabriel that he has seen a "spirit" with "airy gait." 118 That "zealous" spirit initially seems friendly, but Uriel later discerns "his looks / . . with passions foul obscured." 119 That this "old mole" (Shakespeare's language) who has "ventured 
from the deep" (Milton's) is in fact Satan, readers know well; but Milton draws from Hamlet, where Old Hamlet's Ghost appears to Marcellus and Horatio agitated, armed, and frowning: "So frowned [Old Hamlet] once when in an angry parle / He smote the sledded Polacks on the ice." 120 Satan's dismissal of the lowly Zephon recalls the Ghost's refusal to speak to anyone other than Hamlet, even as it registers Satan's even more pronounced status-based diffidence.

Milton's Uriel, Gabriel, Ithuriel, and Zephon even bear similarity to Shakespeare's Marcellus, Horatio, Bernardo, and Francisco. In both rampart scenes, watchmen relate lessons in natural philosophy about matter and spirit. In Hamlet, the soldier Marcellus proposes to "strike at [the ghost] with [his] partisan" before realizing inductively from his failures that the spirit is "as the air invulnerable" and that the humans' "vain blows [are] malicious mockery." 121 Paradise Lost's Gabriel, whose association with Marcellus is amplified by Milton's description of him as "the wingéd warrior," articulates a similar point, but he and Uriel already know what Shakespeare's Marcellus is required to learn, inductively, from experience. ${ }^{122}$ "Hard thou knowst it to exclude / Spiritual substance with corporeal bar," Gabriel says. ${ }^{123}$ It is only when Satan has taken this material form that "Ithuriel with his spear / Touched [him] lightly; for no falsehood can endure / Touch of celestial temper" (4.810-I2). Satan, described by Milton as being thereby transformed into a "grisly king," wants very much to parade his past "glory" like the Ghost of Old Hamlet, but Zephon sets him straight: "Think not, revolted spirit, thy shape the same, / Or undiminished brightness, to be known / As when thou stoodst in heaven upright and pure."124 Whereas Shakespeare's watchmen note the Ghost's eerie resemblances to the man who "smote the sledded Pollacks on the ice," Milton's angels stress difference. "Glory . . . I Departed" is all they see. ${ }^{125}$

However much God's heaven resembles Claudius's Denmark, then, associating Satan with both Old Hamlet and Young Hamlet punctures the Satanic claim to just revenge by ensuring that the Shakespearean traversal emerges as wholly selfauthorized, "sender" and "sent" having collapsed into Satanic unity, nullifying both. Just as the association with Hamlet proves illusory, so too does that with Old Hamlet: Old Hamlet "smote the Pollacks on the ice," but Milton's God is the one responsible for Paradise, "where the morning sun first warmly smote / The open field."126

Milton's allusions, including the telling departure from icy smiting to warm, emphasize that it is the Son, not Satan, whose justice is backed by his Father's authority and whose theatricality arises from just cause. ${ }^{127}$ A key element of the theatrical language from Hamlet that Milton reworks in Paradise Lost involves "putting on." One might expect from the association Milton draws between Satan and Hamlet that Satan would be the only character to "put an antic disposition on" like Hamlet, but as much as Satan, it is the Son who "can put on / [God's] terrors, as ... put [his] mildness on." ${ }^{28}$ Satan's masks, in contrast with the Son's, are more akin to Claudius's than to Hamlet's.

By introducing through Satan the themes of Shakespearean revenge, but reinscribing the Son as the just avenger- "Glory to him whose just avenging ire / Had driven out the ungodly from his sight"-Milton achieves the feat of transforming 
Satan from a sympathetic figure like Hamlet or Old Hamlet into a Claudius. ${ }^{129}$ This is a move with deep relevance to the history of republicanism and the International.

The key idea is that Milton performs a delicate but significant task for the literary history of the International. Milton liberates violent justice against a king from exclusive association with the Satanic, bequeathing to international history instead an English poem capable of deciding that kingly criminals can be brought to justice. For Milton, tyrants as a matter of divine and international law are accountable to others than themselves. There is only a single king, the king of kings, against whom punishment is categorically unjustified.

\section{“Fraternity with All Peoples and War to All Tyrants!"}

"What is the [foreign] policy of the Red Republicans?," George Julian Harney asked. "I answer in the fewest possible words_FRATERNITY WITH ALL PEOPLES AND WAR TO ALL TYRANTS!"130 Milton illustrates that Hamlet too could be read in such a way, with Hamlet's revenge as just punishment for Claudius's tyranny, although many readers from the seventeenth century onward have seen the Ghost who authorizes Hamlet's revenge as a deeply unstable foundation for political organizing. ${ }^{131}$ This latter tradition is the one in which Derrida traffics and through which his New International takes shape. If Milton finds no place in Derrida's literary history of the International, it may be because the "specter of Milton" that Derrida wishes to keep out involves the very decidability of international justice. Marx and Engels rightly understood that republican traditions had profoundly empowering consequences in the making of an international movement. The League of the Just, the Communist League, and the First International were conditioned upon republican conceptions of global citizenship. Skeptical of those empowering consequences and powerfully resistant to big leagues, Derrida's New International on the other hand gains mystique but loses potency as a result of the epistemological uncertainty Derrida conjures in Shakespeare's text. If Shakespeare's play tells us that "divinity doth hedge a king," may we ultimately decide that it does not?

What would change were we to put Miltonic international justice rather than the Derridean Hamlet at the heart of the International instead? Far more than Derrida's Hamlet, Paradise Lost remains open to the possibility of political actions oriented toward international justice founded outside the aristocratic order. Having at its heart a notion of justice as nondomination, Miltonic republicanism offered a language to critique imperialism, to question the legitimacy of dictators, to defend free international discourse, to fight unjust property relations, and to forge new political bonds across national lines. Indeed, theorists like Philip Pettit continue to look to resources in the republican tradition for just such reasons. ${ }^{132}$

Marx thought Milton the republican writing Paradise Lost was like a silkworm producing silk, and that Milton's seventeenth-century revolution was inspiration from below. To conclude, he might have combined these to say that Shakespeare himself was like an old mole digging rapidly through the earth, and that long before Shakespeare inspired Marx, Shakespeare had inspired Milton. In June I850, nearly six months before the first English translation of The Communist Manifesto would appear in The Red Republican, a writer in that newspaper wrote what can serve as a final call 
to incorporate Paradise Lost and its republican Hamlet into the literary history of the International:

The leaders of the English Proletarians have ... progressed from the idea of a simple political reform to the idea of a Social Revolution. Returning lately to this country, after an absence of some years, I was agreeably surprised by this fact. "What, old Mole! Workest thou i' the earth so fast?" The spirit of the age is abroad here too. . . . Paradise ... was never lost . . . it lives—not backwards, in the infancy and youth of humanity,- but in the future, as the bright prize destined for the ripe manhood of the human race $[\ldots] .{ }^{133}$

The author, writing under the pseudonym of Howard Morton, was in fact Helen Macfarlane, the first English translator of The Communist Manifesto, whose translation six months later made a single addition to that world-making text. The addition was a striking expression of civic agency in the International on the part of the translator that ensured, among other things, that she could never be accused of being a "merely artificial" Eve. It is impossible to know whether she would have included Milton among those "leveler pamphleteers" whom she quietly inserted into the literary history of the International. Yet, whereas Moore's more famous translation spoke of the "literature which, in every great modern revolution, has always given voice to the demands of the proletariat, such as the writings of Babeuf and others," Macfarlane's added English specificity: "the literature, which, in all the great revolutions of modern times, has expressed the demands of the proletariat: as leveler pamphleteers, the writings of Babeuf and others." 134 Whether or not Milton qualified in her mind as a Leveller pamphleteer, it was as though Macfarlane's addition had been authorized by a ghost.

\section{NOTES}

For valuable feedback on earlier drafts of this essay, I thank Dan Shore, Carolyn Sale, Rich Purcell, Tony Taylor, and an anonymous reviewer for this journal.

I. Nicholas Royle, The Uncanny: An Introduction (Manchester: Manchester University Press, 2003), 123.

2. Gayatri Chakravorty Spivak, "Ghostwriting," Diacritics 25, no. 2 (July 1995): 65-84; Richard Halpern, "An Impure History of Ghosts: Derrida, Marx, Shakespeare," in Marxist Shakespeares, ed. Jean E. Howard and Scott Cutler Shershow (New York: Routledge, 2000), 3I-52; Tom Nairn, "Internationalism: A Critique," in Faces of Nationalism: Janus Revisited (New York: Verso, 1998), 25-46; Christopher Prendergast, "Derrida's Hamlet," SubStance 34, no. I (2005): 44-47. Halpern's discussion of Max Stirner usefully interrupts the usual story.

3. Friedrich Engels, "Reform Movement in France," Northern Star and National Trades' Journal, December 18, I847; Karl Marx and Frederick Engels, Collected Works, 50 vols. (New York: International Publishers, I975), 6:397-40I, 409-II, hereafter MECW. This quotation, contextualized in more detail below, is the epigraph to one of Christopher Hill's chapters in Christopher Hill, Milton and the English Revolution (New York: Viking, 1978), 165.

4. Jacques Derrida, Specters of Marx: The State of the Debt, the Work of Mourning and the New International (New York: Routledge, 1994), I5. See also Gareth Stedman Jones, "From Republicanism to Communism," in The Communist Manifesto, ed. Gareth Stedman Jones (London: Penguin, 2002), 99-II9. In the interest of scrupulousness, it should be noted that "Milton" does 
appear in Specters of Marx, but only in a quotation from Victor Hugo's Les Miserables, p.II9. That Milton in fact advocated hosticide rather than regicide under the argument that Charles had already "unkinged" himself by the time he was tried was of more importance to Milton than to his nineteenth-century readers. For discussion, see Martin Dzelzainis, "Milton and the Regicide," in John Milton: Life, Writing, Reputation, ed. Paul Hammond and Blair Worden (Oxford: Oxford University Press, 20I0), 9I-I05.

5. Johannes Paulmann, "Searching for a 'Royal International': The Mechanics of Monarchical Relations in Nineteenth-Century Europe," in The Mechanics of Internationalism: Culture, Society, and Politics from the I840s to the First World War, ed. Martin H. Geyer (Oxford: Oxford University Press, 200I), 147-77.

6. Henry Weisser, “Chartist Internationalism, I845-1848," Historical Journal I4, no. I (March 197I): 49-66; Henry Collins and Chimen Abramsky, Karl Marx and the British Labour Movement: Years of the First International (New York: Macmillan, 1965); Mark Mazower, Governing the World: The History of an Idea (New York: Penguin, 20I2); Christine Lattek, "The Beginnings of Socialist Internationalism in the I840's: The 'Democratic Friends of All Nations' in London," in Internationalism in the Labour Movement, I830-1940, ed. Fritz van Holthoon and Marcel van der Linden, vol. I (Leiden: Brill, 1988), 259-82; Gregory Claeys and Christine Lattek, "Radicalism, Republicanism and Revolutionism," in The Cambridge History of Nineteenth-Century Political Thought, ed. Gareth Stedman Jones and Gregory Claeys (Cambridge: Cambridge University Press, 20II), 200-254; Timothy Messer-Kruse, The Yankee International: Marxism and the American Reform Tradition, 1848-1876 (Chapel Hill: University of North Carolina Press, 1998); Richard Sennett, Together: The Rituals, Pleasures and Politics of Cooperation (New Haven, Conn.: Yale University Press, 2012), 35-64.

7. W. J. Linton, "A Republican Catechism," in The Chartist Movement in Britain, I838-1850, ed. Gregory Claeys, vol. 6 (London: Pickering \& Chatto, 200I), 52. Linton was a Chartist and friend and follower of Giuseppe Mazzini.

8. Giuseppe Mazzini, "Toward a Holy Alliance of the Peoples (1849)," in A Cosmopolitanism of Nations: Giuseppe Mazzini's Writings on Democracy, Nation Building, and International Relations (Princeton, N.J.: Princeton University Press, 2009), I2I. For discussion of the broader significance of the Young Europeans' republicanism and internationalism, see Karma Nabulsi, "Patriotism and Internationalism in the 'Oath of Allegiance' to Young Europe," European Journal of Political Theory 5, no. I (January 2006): 6I-70.

9. Karl Marx and Friedrich Engels, The Communist Manifesto, ed. Gareth Stedman Jones (London: Penguin, 2002), 229, 258.

Io. William Shakespeare, Hamlet, ed. G. R Hibbard (Oxford: Oxford University Press, 1987), I.4.64; John Milton, Paradise Lost, ed. Alastair Fowler, 2nd ed. (London: Longman, 1998), 4.663. All further references to Hamlet and to Paradise Lost are to these editions and will be cited by act, scene, and line number or book and line number.

II. Jonathan Rose, The Intellectual Life of the British Working Classes (New Haven, Conn.: Yale University Press, 200I), 26, 36-37, 122-25, 187; Antony Taylor, "Shakespeare and Radicalism: The Uses and Abuses of Shakespeare in Nineteenth-Century Popular Politics," Historical Journal 45, no. 2 (June 2002): 357-79; Albert K. Stevens, "Milton and Chartism," Philological Quarterly I2 (1933): 377-88.

I2. Sharon Achinstein, "Milton's Spectre in the Restoration: Marvell, Dryden, and Literary Enthusiasm," Huntington Library Quarterly 59, no. I (January 1996): I-29. 
13. Harold Bloom, "Milton's Hamlet," in The Anatomy of Influence: Literature as a Way of Life (New Haven, Conn.: Yale University Press, 20II), I05.

I4. Marx's "On the Jewish Question" is the most oft-cited locale for this perspective. For amplification, see most significantly China Miéville, Between Equal Rights: A Marxist Theory of International Law (Chicago: Haymarket Books, 2006). But for a critique, see Robert Knox, "Marxism, International Law, and Political Strategy," Leiden Journal of International Law 22, no. 3 (2009): 4I3-36.

15. Marx and Engels, The Communist Manifesto, 223-24.

I6. Christine Lattek, Revolutionary Refugees: German Socialism in Britain, I840-I860 (London: Routledge, 2006), 32. On the League of the Just, see further Engels, "On the History of the Communist League," in $M E C W$ 26:312-30.

17. Derrida, Specters of Marx, I4.

I8. Ibid., 47; See further Eric Hobsbawm, "Working-Class Internationalism," in Internationalism in the Labour Movement, I830-1940, ed. Fritz van Holthoon and Marcel van der Linden, vol. I (Leiden: Brill, I988), 3-16.

19. Richard Wilson, Shakespeare in French Theory: King of Shadows (New York: Routledge, 2007), 2I, 227.

20. Ibid., 227-4I; Russell Samolsky, “'The Time Is Out of Joint': 'Hamlet,' Messianism, and the Specter of Apocalypse,” English Language Notes 46, no. I (Spring 2008): 29-46.

2I. Jo Guldi and David Armitage, The History Manifesto (Cambridge: Cambridge University Press, 20I4), I.

22. S. S. Prawer, Karl Marx and World Literature (Oxford: Clarendon Press, 1976).

23. Samuel Taylor Coleridge, The Collected Works of Samuel Taylor Coleridge: Lectures, I808I8ı9?: On Literature, ed. Reginald A. Foakes, vol. 5 (Princeton, N.J.: Princeton University Press, 1969), 5:2.272.

24. Shakespeare, Hamlet, 4.5.I20.

25. Derrida, Specters of Marx, I05.

26. Ibid., II4, IO5-I7.

27. Aijaz Ahmad, "Reconciling Derrida: 'Specters of Marx' and Deconstructive Politics," in Ghostly Demarcations: A Symposium on Jacques Derrida's Specters of Marx, ed. Michael Sprinker (London: Verso, 2008), I07; Terry Eagleton, "Marxism without Marxism," in Ghostly Demarcations: A Symposium on Jacques Derrida's Specters of Marx, ed. Michael Sprinker (London: Verso, 2008), 83-87.

28. Derrida, Specters of Marx, I06-7. For recent comments more sympathetic to international institutions, see, for example, Jürgen Habermas and Jacques Derrida, Philosophy in a Time of Terror: Dialogues with Jürgen Habermas and Jacques Derrida (Chicago: University of Chicago Press, 2003), II4, II9; Jacques Derrida, Rogues: Two Essays on Reason, trans. Pascale-Anne Brault and Michael Nass (Stanford, Calif.: Stanford University Press, 2005), 154-55.

29. Milton, Paradise Lost, 4.52I-2.

30. Ahmad, "Reconciling Derrida: 'Specters of Marx' and Deconstructive Politics," IO5.

31. Shakespeare, Hamlet, I.5.I79.

32. Ibid., I.5.I25, I44-45,I65.

33. Derrida, Specters of Marx, 23.

34. The character of Hamlet is not Derrida's only identification. Derrida speaks of Marx's Shakespeare-inspired "theatricalization" of geopolitics and "dramaturgy of modern Europe" before 
quoting a Blanchot essay titled "Marx's Three Voices," in which Blanchot speaks of "three kinds of voices gathering force and taking form [in Marx], all three of which are necessary, but separated and more than opposed." Ibid., 3, I8-20.

Noticing the dramaturgical force of Blanchot's description, Derrida confesses that he "cannot hear" the passage without substituting Shakespeare for Marx. Specters of Marx itself exhibits many of the same performative and dramatic elements found in Shakespeare and Marx, such that what might be called the "three voices of Derrida" correspond, in one reading, to the characters of Hamlet, Horatio, and Marcellus (the three sworn to secrecy in Hamlet I.5) and, in turn, to the three aspects of Derrida's subtitle, the State of the Debt, the Work of Mourning, and The New International. See Christopher Wise, Derrida, Africa, and the Middle East (New York: Palgrave Macmillan, 2009), 75 .

In addition to these three characters, Derrida also professes affinity with Shakespeare's Gravediggers, as Richard Halpern notices, though that identification is troubled, as Halpern rightly observes, by Derrida's apparent unwillingness to "delve in the sometimes unpleasant muck of real history." See Halpern, "An Impure History of Ghosts: Derrida, Marx, Shakespeare," 5 I.

35. Fredric Jameson, "Marx's Purloined Letter," in Ghostly Demarcations, 39; Halpern, "An Impure History of Ghosts: Derrida, Marx, Shakespeare," 33.

36. Derrida, Specters of Marx, $5 \mathrm{I}$.

37. Ibid., I26.

38. Ibid., 47 .

39. Ahmad, "Reconciling Derrida: 'Specters of Marx' and Deconstructive Politics," I07.

40. Marx and Engels, The Communist Manifesto, 218.

4I. See Peter Stallybrass, " 'Well-Grubbed, Old Mole': Marx, Hamlet, and the (Un)fixing of Representation," Cultural Studies I2, no. I (1998): 3; Margreta de Grazia, Hamlet without Hamlet (Cambridge: Cambridge University Press, 2007), 23-44; Martin Harries, "Homo Alludens: Marx’s Eighteenth Brumaire," New German Critique, no. 66 (October 1995): 35-64.

42. Stallybrass, "Well-Grubbed, Old Mole."”

43. Carolyn Sale, "'The King Is a Thing': The King's Prerogative and the Treasure of the Realm in Plowden's Report of the Case of Mines and Shakespeare's Hamlet," in Shakespeare and the Law, ed. Paul Raffield and Gary Watt (Oxford: Hart, 2008), 152.

44. Marx and Engels, The Communist Manifesto, 233.

45. Engels, "Reform Movement in France."

46. Tristram Hunt, The Frock-Coated Communist: The Revolutionary Life of Friedrich Engels (London: Allen Lane, 2009), I3-18.

47. "Louis Blanc's Speech at the Dijon Banquet," in $M E C W, 6: 409-$ II. The $M E C W$ editors suggest that Engels authored the headnote for Marx. While Julius Braunthal gives pride of place to "Thomas Paine, Internationalist," in his three-volume History of the International, he also cites Milton's Areopagitica as an intellectual source for the International. See Julius Braunthal, History of the International, trans. Henry Collins and Kenneth Mitchell, vol. I (New York: Praeger, 1967), 9 .

48. Marshall Grossman, "The Fruits of One's Labor in Miltonic Practice and Marxian Theory," ELH 59, no. I (April 1992): 80. Important exceptions include Joad Raymond, "John Milton, European: Milton and the Rhetoric of the Defenses," in Oxford Handbook of Milton, ed. Nicholas McDowell and Nigel Smith (Oxford: Oxford University Press, 2009), 272-90; David Norbrook, Writing the English Republic: Poetry, Rhetoric and Politics, I627-I660 (Cambridge: 
Cambridge University Press, 1998); David Norbrook, "Women, the Republic of Letters, and the Public Sphere in the Mid-Seventeenth Century," Criticism 46, no. 2 (2004): 223-40; Stephanie Kuduk Weiner, Republican Politics and English Poetry, $1789-1874$ (Basingstoke: Palgrave Macmillan, 2005), 72, 8I-82, I03-4, III.

49. Raphael Samuel, Island Stories: Unravelling Britain, ed. Alison Light, Sally Alexander, and Gareth Stedman Jones (London: Verso, 1998), 284; Tom Clucas, "Editing Milton during the French Revolution: Cowper and Hayley as 'Brother Editor[s],'” Review of English Studies 65, no. 272 (November 2014): 866-87.

50. Joseph Crawford, Raising Milton's Ghost: John Milton and the Sublime of Terror in the Early Romantic Period (London: Bloomsbury Academic, 20II); Tony Davies, "Borrowed Language: Milton, Jefferson, Mirabeau," in Milton and Republicanism, ed. David Armitage et al. (Cambridge: Cambridge University Press, 1995), 264-68, 270; Annabel Patterson, Early Modern Liberalism (Cambridge: Cambridge University Press, 1997), 37. Hollis alone sent copies of Milton's prose, together with John Toland's Life of Milton, to Leipzig, Stockholm, Upsala, Hamburg, Gottingen, Basel, Geneva, and Groningen. See ibid., 59.

5I. Warren Breckman, Marx, the Young Hegelians, and the Origins of Radical Social Theory: Dethroning the Self(Cambridge: Cambridge University Press, 1999), 273.

52. Marx and Engels, $M E C W$, I:I56.

53. Margot C. Finn, After Chartism: Class and Nation in English Radical Politics, I848-1874 (Cambridge: Cambridge University Press, 1993), I34.

54. Stevens, "Milton and Chartism"; James Nelson, The Sublime Puritan (Madison: University of Wisconsin Press, 1963), 74-105; Harry Redman Jr., Major French Milton Critics of the Nineteenth Century (Pittsburgh, Pa.: Duquesne University Press, 1994), 4, II, I23-48; Antony Taylor, "Republicanism Reappraised: Anti-Monarchism and the English Radical Tradition, 18501872," in Re-Reading the Constitution: New Narratives in the Political History of England's Long Nineteenth Century, ed. James Vernon (Cambridge: Cambridge University Press, 1996), 159-60; Anne-Julia Zwierlein, "Milton and the Anti-Slavery Movement," in Majestick Milton: British Imperial Expansion and Transformations of Paradise Lost, 1667-I837 (Berlin: Lit Verlag, 200I), 353-98; Blair Worden, Roundhead Reputations: The English Civil Wars and the Passions of Posterity (New York: Allen Lane, Penguin, 200I), 266-338 ; Claeys and Lattek, "Radicalism, Republicanism and Revolutionism," 208, 236. Erik Gray notes that the publication of De Doctrina Christiana was "a watershed in the history of the poet's reception." See his Milton and the Victorians (Ithaca, N.Y.: Cornell University Press, 2009), 26. There is substantial literature on Milton in the eighteenth century, perhaps most notably Dustin Griffin, Regaining Paradise: Milton and the Eighteenth Century (Cambridge: Cambridge University Press, 1986); Joseph Anthony Wittreich, Feminist Milton (Ithaca, N.Y.: Cornell University Press, 1987).

55. John Milton, Complete Prose Works, ed. Don M. Wolfe (New Haven, Conn.: Yale University Press, 1953), 3:224. Later, Marx as theoretician would use Milton as a positive example of what he called nonproductive labor, contending that "Milton produced Paradise Lost as a silkworm produces silk, as the activation of his own nature" rather than for economic value. For discussion, see Grossman, "The Fruits of One's Labor in Miltonic Practice and Marxian Theory."

56. On the Whig tradition, see Caroline Robbins, The Eighteenth-Century Commonwealthmen: Studies in the Transmission, Development, and Circumstance of English Liberal Thought from the Restoration of Charles II until the War with the Thirteen Colonies (Cambridge, Mass.: Harvard University Press, 1959); Worden, Roundhead Reputations; Patterson, Early Modern Liberalism. 
57. Zwierlein, "Milton and the Anti-Slavery Movement."

58. Philip Pettit, Republicanism: A Theory of Freedom and Government (Oxford: Oxford University Press, 2000), I4I-42; Lattek, "The Beginnings of Socialist Internationalism in the I840's: The 'Democratic Friends of All Nations' in London,” 282.

59. Lattek, Revolutionary Refugees, 23-24. See also Matthew W. Binney, "Milton, Locke, and the Early Modern Framework of Cosmopolitan Right," Modern Language Review I05, no. I (January 20IO): 3I-52.

6o. F. M. Leventhal, Respectable Radical: George Howell and Victorian Working Class Politics (Cambridge, Mass.: Harvard University Press, 1971), 53.

6I. Messer-Kruse, The Yankee International; Robin Blackburn, "Introduction," in Marx and Lincoln: An Unfinished Revolution (London: Verso, 20II), I-IO4.

62. Leventhal, Respectable Radical, I0, 22, 47-48; Finn, After Chartism, I20.

63. Giuseppe Mazzini, "Manifesto of Young Italy (I83I)," in A Cosmopolitanism of Nations, 38.

64. Anon., "Literary Sketches: John Milton," The Chartist Circular, March I3, I84I.

65. Ibid.

66. Milton, Paradise Lost, 7.487-9; Anon., "Literary Sketches: John Milton."

67. Joanna Picciotto, Labors of Innocence in Early Modern England (Cambridge, Mass.:

Harvard University Press, 2010), 468-73.

68. Milton, Paradise Lost, 4.339.

69. Fredric Jameson, "Religion and Ideology: A Political Reading of Paradise Lost," in Paradise Lost: John Milton, ed. William Zunder (New York: St. Martin’s Press, I999), 50.

70. Reginald A. Wilburn, "Malcolm X and African-American Literary Appropriations of Paradise Lost," in Milton in Popular Culture, ed. Laura Knoppers and Gregory M. Colo'n Semenza (New York: Palgrave Macmillan, 2006), I99-2Io. I refer especially to the Satan-like Lord Asriel character in Pullman's His Dark Materials trilogy. Famously, William Empson compared Milton's God to Stalin, suggesting that Milton had a "foreknowledge of the Totalitarian State." Those who concur might wonder as well about Milton's foreknowledge of NATO, the Marshall Plan, and the World Trade Organization. In any case, Shakespeare's Claudius as an alternative model would require no detailed prophesy on Milton's part. William Empson, Milton's God, rev. ed (London: Chatto \& Windus, 1965), I46.

7I. Milton, Paradise Lost, 2.36 .

72. Ibid., I.87-90.

73. Ibid., 2.226, 2.44-45.

74. Ibid., 4.663 .

75. Ibid., I.90-9I, I.89.

76. Ibid., I.376-52I. I am grateful to an anonymous reader for helpful suggestions on this paragraph.

77. David Quint, "Milton's Book of Numbers: Book I of 'Paradise Lost' and Its Catalogue," International Journal of the Classical Tradition $\mathrm{13}$, no. 4 (April 2007): 530.

78. Marx and Engels, "Louis Blanc's Speech at the Dijon Banquet," 399.

79. Milton, Paradise Lost, 6.69, 6.62-63.

8o. Ibid., 4.659 .

8I. John Kerrigan, Revenge Tragedy: Aeschylus to Armageddon (Oxford: Oxford University

Press, I996), I22. 
82. Helen Gardner, "Milton's Satan and the Theme of Damnation in Elizabethan Tragedy," in A Reading of Paradise Lost (Oxford: Clarendon Press, 1965), II4, I2O.

83. De Grazia, Hamlet without Hamlet, I. See also Paul Salisbury Conklin, A History of Hamlet Criticism, I60I-I82I (New York: King's Crown Press, 1947), 3. In Bloom's estimation, "inwardness is far deeper in the Prince of Denmark than it is in [Milton's] Satan," but Milton nevertheless "knowingly" wrote Satan as a "second Hamlet." See Harold Bloom, Bloom's Shakespeare through the Ages: Hamlet (New York: Infobase Publishing, 2008), xiii-xiv; Bloom, "Milton's Hamlet," Sale,

" 'The King Is a Thing': The King's Prerogative and the Treasure of the Realm in Plowden's Report of the Case of Mines and Shakespeare's Hamlet."

84. Sale, "'The King Is a Thing." "

85. Ibid., I54.

86. Nairn, "Internationalism: A Critique," 25; Eric Hobsbawm, "Some Reflections on 'The Break-up of Britain," New Left Review, no. Ios (October 1977): 23.

87. For discussion of the relations between diplomacy and state-building in Hamlet, see Timothy Hampton, Fictions of Embassy: Literature and Diplomacy in Early Modern Europe (Ithaca, N.Y.: Cornell University Press, 2009), 138-62.

88. James Howell, Epistolae Ho-Elianae, or, The Familiar Letters of James Howell (Boston: Houghton, Mifflin and Co., 1907), I26; discussed in Christopher Hill, "The English Revolution and the Brotherhood of Man," in Puritanism and Revolution: Studies in Interpretation of the English Revolution of the Seventeenth Century (New York: St. Martin's Press, 1997), II5.

89. James Holstun, "Communism, George Hill, and the Mir: Was Marx a NineteenthCentury Winstanleyan?," Prose Studies 22, no. 2 (1999): I2I-48.

90. Gerrard Winstanley, "A New-Yeers Gift for the Parliament and the Armie," in Divine Right and Democracy: An Anthology of Political Writing in Stuart England, ed. David Wootton (Indianapolis: Hackett Publishing Company, 2003), 330, 327.

91. Milton, Paradise Lost, I.686-88.

92. Milton, Complete Prose Works, 3.598. Sharon Achinstein analyzes the Cold War contexts for the Yale Prose edition in "Cold War Milton," University of Toronto Quarterly 77, no. 3 (November 2008): 80I-36. See also her "Red Milton: Abraham Polonsky and You Are There (January 30th, 1955)," in Visionary Milton: Essays on Prophecy and Violence, ed. Peter E. Medine, John T. Shawcross, and David V. Urban (Pittsburgh, Pa: Duquesne University Press, 20Io), 4I-6I.

93. Milton, Paradise Lost, 9.782, 9.100I.

94. Nicholas McDowell, "Milton's Regicide Tracts and the Uses of Shakespeare," in Oxford Handbook of Milton, 270; Paul Matholé, "Milton's Use of 'unking'd': An Allusion to Richard II," Notes and Queries 52, no. 3 (2005): 304-7. Perhaps most prominently, Macbeth in particular became an effective way for Milton to chide backsliding Scottish Presbyterians for their fainthearted commitment to the Parliamentarian cause.

95. Geoffrey Robertson, The Tyrannicide Brief: The Story of the Man Who Sent Charles I to the Scaffold (New York: Pantheon, 2006), 3; Raymond, "John Milton, European: Milton and the Rhetoric of the Defenses."

96. Milton, Complete Prose Works, 4:I.34I-43.

97. Ibid., 4:I.340-73, 4.I.658. The Latin is available in John Milton, The Works of John Milton, ed. Frank Allen Patterson (New York: Columbia University Press, 193I), 8:196.

98. John Milton, Complete Shorter Poems, ed. and trans. John Carey, 2nd ed. (London: Longman, 1997), 38-40. 
99. Gordon Campbell, "Shakespeare and the Youth of Milton," Milton Quarterly 33, no. 4 (December 1999): 95-I05. In 1947, Paul S. Conklin could offer a comprehensive survey of allusions to Hamlet that aspired to leave "no item of genuine value in Hamlet criticism between I6OI-I82I ... slighted or overlooked" and make no mention of Milton whatsoever. Conklin, A History of Hamlet Criticism, I60I-I82I, 25. Jonas Barish, The Antitheatrical Prejudice (Berkeley: University of California Press, 198I); David Bevington, Murder Most Foul: Hamlet through the Ages (Oxford: Oxford University Press, 20II). For scholarship revising the usual story, see Paul Stevens, Imagination and the Presence of Shakespeare in Paradise Lost (Madison: University of Wisconsin Press, 1985); Kerrigan, Revenge Tragedy; Timothy Burbery, Milton the Dramatist (Pittsburgh Pa.:

Duquesne University Press, 2007); Ann Baynes Coiro, "Drama in the Epic Style: Narrator, Muse, and Audience in Paradise Lost," Milton Studies 5I (2010): 63-IO0; McDowell, "Milton's Regicide Tracts and the Uses of Shakespeare."

Ioo. David Norbrook, Poetry and Politics in the English Renaissance, rev. ed. (Oxford: Oxford University Press, 2002), 243, 249; Coiro, "Drama in the Epic Style: Narrator, Muse, and Audience in Paradise Lost," 8I.

IOI. Joad Raymond, "The King Is a Thing," in Milton and the Terms of Liberty, ed. Graham Parry and Joad Raymond (Cambridge: D. S. Brewer, 2002), 8I-82.

IO2. For Coiro, Shakespeare's Hamlet stages epistemological challenges that Milton reworks through the voice of the muse in Paradise Lost. In her reading, the poem presents its readerly audience with a quasi-theatrical uncertainty derived from Hamlet: whether to trust the disembodied voice. Coiro, "Drama in the Epic Style: Narrator, Muse, and Audience in Paradise Lost."

I03. Raymond Williams, Politics and Letters: Interviews with New Left Review (New York: Schocken Books, 1979), 335-36.

I04. Ibid.

I05. Milton, Paradise Lost, 2.38.

Io6. Ibid., II.I28-3I, 8.238-39; Shakespeare, Hamlet, I.2.38. Editors sometimes prefer Q2's “delated” or QI's "related” to the First Folio's “dilated.” For discussion, see Patricia Parker, "Othello and Hamlet: Dilation, Spying, and the 'Secret Place' of Woman," Representations, no. 44 (October 1993): 76. As Hampton notes, the name Cornelius "recalls the Cornelian (or Carnelian) gemstone, commonly used as the material for making signet rings.” The name's association with mining may be equally significant in this context. Hampton, Fictions of Embassy, I48.

I07. Norbrook, Writing the English Republic, 475-76. On the international contexts of Milton's interest in elective monarchy in the I66os, see also Martin Dzelzainis, "'What a Do with the Kings and the Statues Is Here': Milton, Marvell, and John Sobieski," in Collaboration and Interdisciplinarity in the Republic of Letters: Essays in Honour of Richard G. Maber, ed. Paul Scott (Manchester: Manchester University Press, 2010).

108. Milton, Paradise Lost, 5.606, 6.707, I.98. Telling readers that on the day the Son's installation was announced in heaven "All seemed well pleased; all seemed, but were not all" (5.617), Milton may even be slyly echoing Hamlet's "Seems, madam? Nay it is. I know not 'seems'” while raising the possibility that Satan (both before and after Hamlet) had "that within which passeth show" (I.2.85).

I09. Shakespeare, Hamlet, I.5.59-60; Margreta de Grazia, “'Old Mole’: The Modern Telos and the Return to Dust," in Hamlet without Hamlet (Cambridge: Cambridge University Press, 2007), 36.

IIo. Shakespeare, Hamlet, I.5.63; Milton, Paradise Lost, 4.800-802. 
III. Shakespeare, Hamlet, I.2.I3. On legal issues surrounding marriage in Hamlet, see Lisa Jardine, “'No Offence I’ Th' World': Unlawful Marriage in Hamlet,” in Reading Shakespeare Historically (London: Routledge, I996), 35-47; Jason Rosenblatt, "Hamlet, Henry, Epicone, and Hebraica: Marriage Questions," in Renaissance England's Chief Rabbi: John Selden (Oxford: Oxford University Press, 2006), I4-53. On republicanism and marriage, see Sharon Achinstein, "Saints or Citizens? Ideas of Marriage in Seventeenth-Century English Republicanism," The Seventeenth Century 25 (October 2010): 240-64.

II2. Milton, Paradise Lost, 4.947-48.

II3. Ibid., 4.889-94.

II4. Shakespeare, Hamlet, 2.2.582.

II5. Milton, Complete Prose Works, 2:527.

II6. Milton, Paradise Lost, 4.851-52.

II7. Ibid., 4.852 .

II8. Ibid., 4.565, 568 .

II9. Ibid., 4.565, 4.570-7I.

I20. Ibid., 4.574; Shakespeare, Hamlet, I.I.62-63

I2I. Shakespeare, Hamlet, I.I.I2I, I25-26.

I22. Milton, Paradise Lost, 4.576 .

I23. Ibid., 4.584-85.

I24. Ibid., 4.82I, 4.838, $4.835-37$.

I25. Ibid., 4.838-39.

I26. Ibid., 4.244-45 (emphasis added).

I27. For a related argument that "the atonement draws Paradise Lost towards revenge tragedy in ways more profound yet also more subtle than those involved in Satan's campaign against humanity," see Kerrigan, Revenge Tragedy, I23ff.

128. Milton, Paradise Lost, 6.734-35.

I29. Ibid., 7.184-85.

130. George Julian Harney, ed., The Red Republican and The Friend of the People (New York: Barnes and Noble, 1966), 60.

I3I. In the Balkans, for example, supporters of Slobodan Milošević staged Hamlet to illustrate "what happens when individuals tamper with power and refuse to sublimate their own ambitions for the benefit of the community." See Chris Hedges, War Is a Force That Gives Us Meaning (New York: PublicAffairs, 2002), 78-79.

132. Philip Pettit, "Legitimate International Institutions: A Neo-Republican Perspective," in The Philosophy of International Law, ed. Samantha Besson and John Tasioulas (Oxford: Oxford University Press, 2010); Philip Pettit, “A Republican Law of Peoples,” European Journal of Political Theory 9, no. I (2010): 70-94.

133. Howard Morton [Helen Macfarlane], "Chartism in I850," The Red Republican, June 22, I850.

134. Cited from Marx and Engels, The Communist Manifesto, 253; "The Communist Manifesto: Helen Macfarlane's I850 Translation," in Helen Macfarlane: A Feminist, Revolutionary Journalist, and Philosopher in Mid-Nineteenth-Century England, ed. David Black, trans. Helen Macfarlane (Lanham, Md.: Lexington Books, 2004), I67. 